\title{
PENINGKATAN HASIL BELAJAR IPA MATERI DAUR HIDUP HEWAN MENGGUNAKAN MEDIA CIRCLE CARTON PADA SISWA KELAS IV SDN SEMPOL 04 KECAMATAN PAGAK KABUPATEN MALANG
}

\author{
Ulfa Yulina \\ e-mail: ulfa.uy@gmail.com
}

\begin{abstract}
This study aims to describe the implementation and improvement of learning outcomes animal life cycle material science using the media Circle Carton. This research is Classroom Action Research (CAR). Action research subjects are students of class IV Elementary School District of Pagak Sempol 04 Malang academic year 2013/2014 Semester 1, amounting to 16 students. The results of this research is the application of Circle Carton media can improve learning outcomes lifecycle material science grade IV Elementary School District of Pagak Sempol 04 Malang academic year 2013/2014. The steps of learning are (a) student motivation, (b) deliver the learning objectives, (c) the division of the group, (d) the delivery of learning, (e) deliver media usage guide Circle Carton, (f) distributing media at the Circle Carton each group, (g) students working on a group assignment, (h) the presentation of the group, (i) collecting the task group, $(\mathrm{j})$ and individual evaluation $(\mathrm{k})$ conclusion.
\end{abstract}

\begin{abstract}
Abstrak: Penelitian ini bertujuan untuk mendeskripsikan pelaksanaan dan peningkatan hasil belajar IPA materi daur hidup hewan dengan menggunakan media Circle Carton. Jenis penelitian ini adalah Penelitian Tindakan Kelas (PTK). Subjek penelitian ini adalah siswa kelas IV SDN Sempol 04 Kecamatan Pagak Kabupaten Malang tahun pelajaran 2013/2014 semester 1 yang berjumlah 16 siswa. Hasil penelitian ini adalah penerapan media Circle Carton dapat meningkatkan hasil belajar IPA materi daur hidup siswa kelas IV SDN Sempol 04 Kecamatan Pagak Kabupaten Malang tahun pelajaran 2013/2014. Adapun langkah-langkah pembelajarannya adalah (a) motivasi siswa, (b) penyampaikan tujuan pembelajaran, (c) pembagian kelompok, (d) menyampaikan pembelajaran, (e) menyampaikan panduan penggunaan media Circle Carton, (f) pembagikan media Circle Carton pada pada setiap kelompok, (g) siswa mengerjakan tugas kelompok, (h) presentasi kelompok, (i) mengumpulkan tugas kelompok, (j) evaluasi secara individu dan $(\mathrm{k})$ penarikan kesimpulan.
\end{abstract}

Kata Kunci: pembelajaran IPA SD, media circle carton, hasil belajar

Pendidikan merupakan salah satu kegiatan universal dalam kegiatan manusia. Hal ini terbukti pada kehidupan manusia dalam masyarakat tidak dapat berlangsung dengan baik tanpa adanya interpretasi yang berlangsung. Menurut Bratanata dkk (dalam Ahmadi, 2003:69) pendidikan adalah usaha yang sengaja diadakan baik langsung maupun tidak langsung untuk membantu anak dalam perkembangannya mencapai kedewasaan. Pendapat tersebut sejalan dengan Sistem Pendidikan Nasional (undang-undang Nomor 20 Tahun 2003) yang men- jelaskan bahwa pendidikan adalah usaha sadar dan terencana untuk mewujudkan suasana belajar dan proses pembelajaran agar peserta didik secara aktif mengembangkan potensi dirinya untuk memilih kekuatan spiritual keagamaan, pengendalian diri, kepribadian, kecerdasan, akhlak mulia, serta keterampilan yang diperlukan dirinya, masyarakat, bangsa dan negara.

Usaha sadar dan terencana yang dapat dilakukan oleh guru adalah menciptakan dan menyusun pembelajaran yang kreatif dan inovatif serta mampu 
menggunakan apa yang ada di lingkungan sekitar sebagai media pembelajaran yang dapat membantu siswa dalam meningkatkan hasil belajar.

Hasil belajar adalah perubahan perilaku peserta didik akibat belajar. Perubahan perilaku disebabkan karena dia mencapai penguasaan atas sejumlah bahan yang diberikan dalam proses belajar mengajar (Sudjana: 2008). Menurut Benyamin S. Bloom dalam Arifin (2009: 21), penilaian hasil belajar terdapat tiga ranah yaitu (1) ranah kognitif, (2) ranah afektif, (3) ranah psikomotorik. Ranah kognitif yaitu segala upaya yang menyangkut aktivitas otak termasuk ranah proses berpikir. Ranah Afektif berkenaan dengan sikap seseorang dan ranah psikomotorik adalah yang berkaitan dengan keterampilan atau kemampuan bertindak setelah siswa menerima pengalaman belajar tertentu. Dalam setiap mata pelajaran penilaian diambil dari tiga ranah yaitu kognitif, afektif, psikomotorik dan termasuk pada mata pelajaran Ilmu Pengetahuan Alam (IPA).

Ilmu Pengetahuan Alam (IPA) merupakan salah satu mata pelajaran di Sekolah Dasar yang memiliki hubungan erat dengan lingkungan sekitar dan kehidupan sehari-hari, seharusnya disajikan melalui suatu pembelajaran yang berkualitas agar dapat memberikan pengalaman langsung bagi siswa sehingga pembelajaran menjadi bermakna bagi siswa.

Kebermaknaan belajar sebagai hasil dari peristiwa mengajar ditandai oleh terjadinya hubungan substantif antara aspek-aspek, konsep-konsep, informasi/ situasi baru dengan komponen-komponen yang relevan di dalam struktur kognitif siswa (Rusman, 2012: 252). Hal ini berarti bahwa belajar tidak hanya menghafal konsep-konsep atau fakta-fakta, namun berusaha menghubungkan kansepkonsep tersebut untuk menghasilkan pemahaman yang utuh, sehingga konsep yang dipelajari tersebut akan dipahami secara baik dan tidak akan dilupakan.

Hasil pengamatan pembelajaran IPA materi daur hidup hewan di SDN Sempol 04 Kecamatan Pagak Kabupaten Malang pada tanggal 3 September 2013 menunjukkan bahwa hasil ketuntasan belajar siswa rendah. Hal ini ditunjukkan oleh hasil belajar yang dicapai siswa belum sesuai dengan KKM yang telah ditentukan oleh guru. KKM untuk Ilmu Pengetahuan Alam yaitu ketuntasan individu adalah 60 dan ketuntasan klasikal (KK) adalah $60 \%$. Berdasarkan data yang diperoleh dari 16 siswa ketika diadakan penilaian formatif awal, 10 siswa (62,5\%) mendapat nilai di bawah KKM dan 6 siswa $(37,5 \%)$ mendapat nilai diatas KKM. Berdasarkan hasil wawancara dengan wali kelas IV, hal ini dikarenakan masih banyak siswa yang masih kurang memahami materi yang disampaikan oleh guru. Selain itu, ada juga beberapa siswa yang tidak fokus dalam proses belajar mengajar dan ramai sendiri.

Hal ini terjadi karena proses pembelajaran masih berpusat pada guru (teacher centred), metode pembelajaran kurang bervariasi, guru hanya menerangkan, sedangkan siswa mencatat hal-hal penting dan memberi tugas sehingga siswa tidak dapat mengembangkan kemampuan yang dimiliki dan kurang berminat dalam pembelajaran. Situasi kelas yang seperti ini menjadikan siswa kurang aktif dan terkesan pasif dalam pembelajaran. Peran siswa dalam pembelajaran masih belum menyeluruh karena masih didominasi oleh siswa yang aktif. Siswa yang aktif tersebut cenderung lebih suka bertanya dan menggali informasi dari guru sehingga siswa tersebut memiliki tingkat pemahaman yang lebih dibandingkan siswa yang kurang aktif.

Pembelajaran akan lebih bermakna apabila siswa berperan aktif dalam pembelajaran, dengan begitu siswa akan ter- 
pembelajaran. Keterlibatan siswa secara langsung dalam pembelajaran merupakan salah satu faktor yang berpengaruh terhadap keberhasilan siswa. Suatu konsep akan lebih mudah dipahami dan diingat oleh siswa jika konsep tersebut disajikan melalui prosedur-prosedur yang tepat, jelas dan menarik sehingga siswa mampu memahami konsep yang disampaikan. Salah satu faktor utama yang dapat mengaktifkan siswa adalah dengan menggunakan media pembelajaran yang menarik dan dapat melibatkan siswa secara langsung. Menurut Sanjaya (2008: 209), penggunaan media dapat menambah motivasi belajar siswa sehingga perhatian siswa terhadap materi pembelajaran dapat lebih meningkat.

Salah satu media yang dapat digunakan untuk meningkatkan hasil belajar siswa adalah media Circle Carton. Media Circle Carton adalah media yang dirancang untuk mengaktifkan proses belajar siswa dan membantu dalam memahami materi yang disampaikan oleh guru. Media Circle Carton ini dirancang sebagai alat bantu yang dapat meningkatkan pemahaman siswa dan meningkatkan hasil belajar siswa, karena media Circle Carton ini didesain seperti mainan sehingga siswa lebih tertarik dan termotivasi dalam proses belajar. Yamin (2009:151) mengungkapkan salah satu manfaat dari media pembelajaran adalah pembelajaran menjadi lebih interaktif. Hal ini dapat meningkatkan pemahaman siswa terhadap materi yang diajarkan sehingga dapat meningkatkan minat dan motivasi siswa dalam pembelajaran dan juga dapat meningkatkan hasil belajar siswa.

Hasil penelitian terdahulu yang dilakukan oleh Sulistyo (2009) dengan menggunakan media lingkaran undangundang pada materi Tata Urutan Peraturan Perundang-undangan pada siswa kelas VIII D SMP Negeri 2 Purwoasri Ka- bupaten Kediri dapat meningkatkan hasil belajar siswa. Selanjutnya hasil penelitian yang dilakukan oleh Sholihatur Rahmah (2011) dengan dengan menerapan pembelajaran Aktif Student-Created $\mathrm{Ca}$ se Studies dalam meningkatkan hasil belajar siswa kelas IV SDN Bawang $3 \mathrm{Ke}-$ diri dapat meningkatkan hasil belajar siswa.

Berdasarkan dipaparkan tersebut di atas, maka peneliti akan melakukan penelitian dengan judul "Peningkatan $\mathrm{Ha}$ sil Belajar IPA Materi Daur Hidup Hewan Menggunakan Media Circle Carton Siswa Kelas IV SDN Sempol 04 KecamaKecamatan Pagak Kabupaten Malang".

\section{METODE PENELITIAN}

Jenis penelitian yang digunakan dalam penelitian ini adalah jenis penelitian tindakan (Action Research). Desain penelitian yang akan digunakan adalah Penelitian Tindakan Kelas (Classroom Action Research). Penelitian Tindakan Kelas (PTK) adalah proses pengkajian masalah pembelajaran di dalam kelas melalui refleksi diri dalam upaya memecahkan masalah dengan cara melakukan tindakan yang terencana dalam situasi nyata serta menganalisis setiap pengaruh dari perlakuan tersebut (Sanjaya, 2010: 26).

Mulyasa (2010: 11) mengartikan PTK sebagai suatu upaya untuk mencermati kegiatan belajar sekelompok peserta didik dengan memberikan sebuah tindakan (treatment) yang sengaja dimunculkan. Tindakan yang dilakukan oleh guru bersama-sama dengan siswa dengan arahan dan bimbingan dari guru untuk memperbaiki dan meningkatkan kualitas pembelajaraan.

Berdasarkan kedua pendapat diatas dapat disimpulkan bahwa Penelitian Tindakan Kelas (PTK) adalah suatu tindakan terencana yang dilakukan oleh guru 
untuk perbaikan dan peningkatan kualitas pembelajaran serta menganalisis segala perlakuan yang dilakukan. Menurut Kemmis dan Taggart dalam Wiriatmadja (2010: 66) proses tindakan dimulai dengan melakukan perencanaan (planniing), pelaksanaan (acting), pengamatan (observing), dan refleksi (reflecting) yang berbentuk spiral dari siklus satu ke siklus selanjutnya. Langkah pada siklus selanjutnya adalah perencanaan yang telah direvisi, tindakan, pengamatan dan refleksi.

Dalam penelitian tindakan ini menggunakan bentuk penelitian kolaboratif yang bertujuan untuk meningkatkan kualitas pembelajaran di kelas, dimana guru terlibat langsung dalam penelitian penelitian mulai dari perencanaan, pelaksanaan tindakan, pengamatan serta refleksi. Pada penelitian ini peneliti bekerjasama dengan guru kelas SDN Sempol 04 Kecamatan Pagak Kabupaten Malang, peneliti sebagai pengajar dan observer yang dibantu oleh teman mahasiswa dari PGSD UMM.

Prosedur pengumpulan data yang dalam penelitian ini berupa lembar pengamatan aktivitas guru dan siswa, wawancara, tes hasil belajar siswa dan dokumentasi. Data yang diperoleh dalam penelitian ini adalah data dari proses dan hasil. Data merupakan segala sesuatu yang perlu dianalisis yakni diolah dan diinterpretasikan sehingga data itu memberikan informasi yang berarti khususnya untuk guru dalam proses perbaikan kualitas pembelajaran (Sanjaya, 2010: 105). Data proses merupakan data tentang kegiatan guru dalam proses pembelajaran dengan menggunakan media Circle Carton dan data aktivitas siswa selama mengikuti kegiatan berlangsung. Sedangkan data hasil merupakan data hasil belajar siswa yang diperoleh dari hasil evaluasi siswa yang dilakukan pada setiap akhir pertemuan.
Teknik analisis data yang digunakan dalam penelitian tindakan kelas ini meliputi: (a) data hasil wawancara dengan menyederhanakan hasil wawancara, menyajikan data dengan mndeskripsikan dalam bentuk paparan data dan menyimpulkan data yang diperoleh. (b) Penyimpulan data hasil observasi guru dan siswa dilakukan dengan melihat lembar hasil observasi yang telah diisi oleh observer selama pembelajaran berlangsung dan komentar perbaikan dari observer. (c) Hasil belajar siswa dapat diketahui dari hasil tes evaluasi yang diberikan pada setiap akhir pertemuan.

\section{HASIL PENELITIAN}

Data penelitian menunjukkan bahwa dari hasil observasi pembelajaran pada siklus I dan II sudah terlaksana sesuai ngan rencana pembelajaran. Untuk depengamatan aktivitas guru pada Siklus I masih ada beberapa hal yang harus diperbaiki oleh guru pada pembelajaran yaitu guru kurang dapat membangun suasana kelas yang menyenangkan dan teknik bertanya kurang menarik. Pada siklus II, kekurangan yang ada pada siklus I sudah diperbaiki dan berjalan dengan baik sesuai dengan rencana perbaikan yang dibuat sebelum pelaksanaan siklus selanjutnya.

Pada hasil pengamatan aktivitas siswa selama proses pembelajaran Siklus I siswa masih kurang dalam hal kerjasama dengan baik dengan anggota kelompoknya, untuk itu guru membuat peraturan dalam kerja kelompok, sehingga siswa lebih meningkatkan kerjasama dengan anggota kelompoknya. Selain itu siswa juga masih belum dapat melakukan tanya jawab dengan baik dengan guru dan siswa yang lain, untuk itu guru memberi motivasi kepada siswa dengan memberi "smile" pada siswa yang bertanya kepada guru dan aktif dalam pem- 
belajaran, dimana pada akhir pertemuan nanti siswa yang paling banyak mendapatkan "smile" akan mendapatkan hadiah atau reward dari guru. Pada Siklus II siswa sudah mampu melakukan tanya jawab dengan baik kepada guru dan teman-temannya.

Dari pembelajaran ini juga dapat diketahui rata-rata hasil belajar siswa mengalami peningkatan. Rata-rata hasil belajar siswa siklus I sebesar 56,3\% dengan kategori cukup untuk itu masih perlu dilakukan perbaikan pada siklus selanjutnya. Pada siklus II rata-rata hasil belajar siswa mengalami peningkat menjadi $87,5 \%$ dengan kategori baik. Hal ini menunjukkan bahwa pembelajaran dengan menggunakan media Circle Carton memungkinkan untuk dijadikan sebagai salah satu alternatif media pembelajaran yang dapat membantu siswa dalam memahami materi serta dapat meningkatkan hasil belajar siswa.

\section{PEMBAHASAN}

Media Circle Carton ini merupakan media yang dapat menyalurkan pesan yang berupa rangkuman dari materi. Media Circle Carton ini termasuk dalam media visual dimana media visual merupakan media yang menampilkan gambar diam. Menurut Munadi (2013: 81) mengemukakan bahwa media visual adalah media yang melibatkan indera penglihatan. Selain itu Munadi juga mengemukakan terdapat dua jenis pesan yang dimuat dalam media visual yaitu pesan verbal dan nonverbal. Pesan verbal-visual terdiri atas kata-kata dalam bentuk tulisan dan pesan nonverbal-visual adalah pesan yang disampaikan kedalam simbolsimbol.

Karakteristik media visual ada tiga, yang pertama yaitu pesan visual yang dapat disampaikan dalam bentuk gambar, grafik, diagram, bagan dan peta.
Kedua penyaluran pesan visual verbalnonverbal-grafis yang disampaikan dalam bentuk buku dan modul, komik, majalah dan jurnal, poster dan papan visual. Ketiga yaitu benda asli dan benda tiruan (model). Dalam hal ini media Circle Carton termasuk dalam karakteristik yang kedua yaitu penyaluran pesan visual verbal-nonverbal-grafis dengan penyampaian pesannya berupa papan visual. Papan visual adalah papan yang dapat menyalurkan pesan-pesan visual(Munadi , 2013:103). Hal tersebut sesuai dengan media Circle Carton, dimana dalam media tersebut terdapat rangkuman materi yang akan dipelajari.

Banyak kelebihan yang didapat siswa dalam proses pembelajaran dengan menggunakan media Circle Carton, diantaranya yaitu: (1) mempunyai desain yang menarik sehingga mampu memotivasi siswa, (2) merupakan media atau sarana belajar sambil bermain, (3) meningkatkan kerjasama antar siswa dalam kegiatan kelompok, dan (4) melibatkan siswa secara aktif dalam pembelajaran. Hal tersebut sesuai dengan pernyataan $\mathrm{Mu}-$ nadi (2013:47), bahwa menurut fungsinya media pembelajaran dapat membangkitkan memotivasi siswa dalam menerima dan memahami isi pembelajaran yang disampaikan oleh guru. Tugas guru dalam memotivasi siswa adalah mendorong, mengaktifkan dan menggerakkan siswa secara sadar untuk terlibat aktif dalam proses pembelajaran.

Penelitian dengan menggunakan media Circle Carton pada pembelajaran IPA materi daur hidup hewan pada siswa kelas IV SDN Sempol 04 Kecamatan Pagak Kabupaten Malang. Temuan yang diperoleh dalam penelitian ini adalah pembelajaran yang menyenangkan dan dapat meningkatkan keaktifan siswa dalam pembelajaran. Keaktifan siswa dalam pembelajaran tersebut dapat berpengaruh terhadap hasil belajar siswa. Me- 
nurut Sudjana (2008: 3) hasil belajar adalah proses pemberian nilai terhadap hasil-hasil belajar yang dicapai siswa dengan kriteria tertentu. Pada hakikatnya hasil belajar siswa merupakan perubahan tingkah laku yang mencakup bidang kognitif, afektif dan psikomotoris. Hasil belajar siswa dapat diketahui dari hasil evaluasi pada setiap akhir pertemuan. Berdasarkan data hasil penelitian hasil belajar siswa pada Siklus II mengalami peningkatan dari hasil Siklus I. Peningkatan hasil belajar ini menunjukkan bahwa media Circle Carton mampu meningkatkan hasil belajar IPA materi daur hidup hewan di SDN Sempol 04 kecamatan Pagak Kabupaten Malang. Peningkatan hasil belajar siswa pada siklus I sebesar $56,3 \%$ atau sebanyak 9 siswa yang tuntas dengan ketuntasan klasikal sebesar 56,3\% sehingga belum mencapai ketuntasan klasikal yang diterapkan oleh sekolah yaitu $\geq 60 \%$ dan masih membutuhkan perbaikan pembelajaran pada siklus selanjutnya. Pada siklus II, hasil belajar siswa mengalami peningkat menjadi $87,5 \%$ atau sebanyak 14 siswa yang tuntas dengan ketuntasan klasikal 87,5\%, sehingga dapat dikatakan sudah mencapai ketuntasan klasikal yang telah ditentukan yaitu $\geq 60 \%$ dan dinyatakan penelitian akan dihentikan harena sudah mencapai kriteria yang telah ditentukan. Peneliti melakukan pe- nelitian sebanyak 2 siklus, dimana dalam 1 siklus terdapat dua pertemuan. Hasil belajar siswa dari siklus I meningkat sebanyak $31,2 \%$ ke siklus II.

Siswa yang tidak tuntas pada siklus II merupakan siswa yang tidak tuntas pada siklus I dan siklus II. Dari hasil analisis 2 siswa yang tidak tuntas tersebut sudah mengalami peningkatan hasil belajarnya namun peningkatan tersebut masih kurang mencapai KKM yang telah dientukan oeh sekolah yaitu 60 untuk mata pelajaran IPA. Pening- katan hasil belajar siswa pada penelitian ini tidak lepas dari penerapan media Circle Carton pada pembelajaran IPA materi daur hidup hewan secara sederhana. Setelah melalui proses belajar maka siswa diharapkan dapat mencapai tujuan belajar yang disebut juga sebagai hasil belajar. Seperti yang telah disebutkan di- atas hasil belajar merupakan perubahan $\mathrm{t}$ tingkah laku pada siswa setelah mene- rima pengalaman belajar. Pengalaman belajar yang dialami oleh siswa diharap- kan dapat memberikan pembelajaran ya- ng bermakna pada siswa. Hal tersebut sejalan dengan pendapat yang dikemukakan oleh Rusman (2012:253) bahwa belajar akan lebih bermakna jika anak mengalami apa yang dipelajarinya langsung.

Pendidikan dan pengajaran dikatakan berhasil apabila perubahan. Perubahan yang tampak pada siswa harus merupakan akibat dari proses belajar mengajaran yang dialami. Menurut Suyono (2011:13) bahwa belajar merupakan suatu proses perubahan tingkah laku akibat pengalaman yang relatif menetap dan menuju kebaikan yang positif. Pada proses pembelajaran berbagai macam cara di dilakukan oleh guru untuk meningkatkan hasil belajar siswa salah satunya yaitu dengan menggunakan media Circle Carton dalam pembelajaran IPA materi daur hidup hewan secara sederhana. Jika menggunakan media Circle Carton pada materi daur hidup hewan secara seder- hana siswa kelas IV SDN Sempol 04 Kecamatan Pagak Kabupaten Malang dapat meningkatkan hasil belajar adalah terbukti.

Media Circle Carton merupakan media yang dirancang sebagai alat bantu untuk meningkatkan pemahaman siswa dan meningkatan hasil belajar siswa. Media Circle Carton ini didesain seperti mainan yang dapat diputar sehingga siswa lebih tertarik dan termotivasi dalam 
proses belajar. Yamin (2009:151) mengungkapkan salah satu manfaat dari media pembelajaran adalah pembelajaran menjadi lebih interaktif. Hal ini dapat meningkatkan pemahaman siswa terhadap materi yang diajarkan sehingga dapat meningkatkan minat dan motivasi siswa dalam pembelajaran dan juga dapa meningkatkan hasil belajar siswa. Pendapat tersebut sejalan dengan salah satu fungsi media pembelajaran yang di- kemukakan oleh Suprihatiningrum (2013:320) yaitu media pembelajaran harus dapat memotivasi. Hal ini berarti media pembelajaran yang digunakan harus dapat menumbuhkan kesadaran siswa untuk lebih giat dalam belajar.

\section{KESIMPULAN}

Penggunaan media Circle Carton dalam pembelajaran IPA materi daur hidup hewan secara sederhana dilaksanakan sesuai dengan sintak pembelajaran. Langkah-langkah pembelajaran dalam penelitian ini adalah Adapun langkahlangkah pembelajarannya adalah (a) motivasi siswa, (b) penyampaikan tujuan pembelajaran, (c) pembagian kelompok, (d) penyampaian pembelajaran, (e) penyampaikan panduan penggunaan media Circle Carton, (f) pembagikan media Circle Carton pada setiap kelompok, (g) siswa mengerjakan tugas kelo kelompok, (h) presentasi kelompok, (i) mengumpulkan tugas kelompok, (j) evaluasi secara individu dan $(\mathrm{k})$ penarikan kesimpulan.

Pelaksanaan kegiatan pembelajaran sudah sesuai dengan langka-langkah pembelajaran tersebut diatas dan sudah terselenggara dengan baik. Hal ini ditandai dengan adanya peningkatan perbaikan guru dalam mengajar serta aktivitas siswa selama pembelajaran berlangsung. Berdasarkan hasil temuan diatas dapat diketahui juga ketuntasan belajar siswa dari Siklus I dan II yang meng- alami peningkatan. Pada siklus I sebesar $56,3 \%$ yang tuntas dengan ketuntasan klasikal sebesar $56,3 \%$ sehingga belum mencapai ketuntasan klasikal yang diterapkan oleh sekolah yaitu $\geq 60 \%$ dan masih membutuhkan perbaikan pembelajaran pada siklus selanjutnya. Pada siklus II, hasil belajar siswa mengalami peningkat menjadi $87,5 \%$ yang tuntas dengan ketuntasan klasikal 87,5\% sehingga, dapat dikatakan sudah mencapai ketuntasan klasikal yang telah ditentukan yaitu $\geq 60 \%$ dan dinyatakan penelitian akan dihentikan harena sudah mencapai kriteria yang telah ditentukan.

\section{SARAN}

Beberapa saran yang dapat disampaikan berdasarkan penelitian ini adalah hendaknya guru ampu menguasai kelas secara kondusif dan memberikan bimbi bimbingan kepada siswa secara menyeluruh sehingga keaktifan dan partisipasi siswa dalam pembelajaran tetap ada sehingga pembelajaran yang dilakukan akan lebih bermakna.

\section{DAFTAR PUSTAKA}

Ahmadi, Abu \& Nur Uhbiyati, 2001. Ilmu Pendidikan (Cetakan kedua) .Jakarta: PT Rineke Cipta.

Arifin, Zainal, 2009. Evaluasi Pembelajaran. Bandung: PT Remaja Rosdakarya.

Mulyasa, 2010. Praktik Penelitian Tindakan Kelas. Bandung: PT Remaja Rosdakarya.

Munadi, Yudhi, 2013. Media Pembelajaran (Sebuah Pendekatan Baru). Jakarta: Gaung Persada Press Group.

Rusman, 2012. Model-Mode Pembelajaran (Mengembangkan Profesional Guru). Jakarta: Rajawali Pers.

Sanjaya, Wina, 2008. Perencanaan dan Desain Sistem Pembelajaran. Ja- 
karta: Kencana Prenada Media Group.

Sanjaya, Wina. 2010. Penelitian Tindakan Kelas. Jakarta: Kencana Prenada Media Group.

Sholihatur Rohma, Dewi. 2011. Penerapan Pembelajaran Aktif StudentCreated Case Studies dalam Meningkatkan Hasil Belajar Siswa Kelas IV SDN Bawang 3 Kediri Tahun Pelajaran 2010/2011. Kediri: Tidak diterbitkan.

Sudjana, Nana, 2008. Penilaian Hasil Proses Belajar Mengajar. Bandung: PT Remaja Rosdakarya.

Sulistyo, Joko, 2009. Peningkatan Pembelajaran Pkn Tentang Tata Urutan Peraturan Perundang-Undangan Nasional Melalui Media Lingkaran Undang-undang Siswa Kelas VIIID Semester 1 Tahun Pelajaran 2009/2010 di SMP Negeri 2 Purwoasri Kabupaten Kediri. Kediri: Tidak diterbitkan.

Suprihatiningrum, Jamil, 2012. Strategi Pembelajaran (Teori \& Aplikasi). Yogyakarta: AR-Ruzz Media.

Suyono \& Hariyanto, 2011. Belajar dan Pembelajaran (Teori dan Konsep Dasar). Bandung: PT. Remaja Rosdakarya.

Wiriatmadja, R. 2010. Metode Penelitian Tindakan Kelas: untuk Meningkatkan Kinerja Guru Dan Dosen Bandung: PT Remaja Rosdakarya.

Yamin, Martinis \& Bansu I Ansari, 2009. Teknik Mengembangkan Kemampuan Individual Siswa. Jakarta : Gaung Persada Press. 